\title{
Kualitas Pelayanan Terhadap Penjualan Kamar Hotel Bagi Wisatawan di Bandung
}

\author{
Heni Rohaeni ${ }^{1}$, Ane Widaini ${ }^{2}$ \\ 1'ASM BSI, heniaj.hri@gmail.com \\ ${ }^{2}$ ASM BSI, Anewidaini1610@gmail.com
}

\begin{abstract}
ABSTRAK
Perusahaan yang bergerak dalam bidang jasa memandang pelanggan sebagai faktor yang penting. Pelanggan yang puas atas jasa yang ditawarkan, merupakan tanda positif bagi suatu perusahaan. Guna mewujudkan rasa puas pada pelanggan, maka perusahaan harus mampu memberikan pelayanan sesuai dengan atau melebihi harapan pelanggan, karena semakin baik pelayanan yang diberikan maka pelanggan akan semakin puas. Ini akan berpengaruh pada peningkatan laba yang di peroleh perusahaan. Penelitian ini bertujuan untuk mengetahui kualitas pelayanan terhadap penjualan kamar Hotel bagi Wisatawan pengguna jasa layanan Hotel Di Bandung. Metode penelitian yang digunakan pada penelitian ini adalah metode kuantitatif, melalui penyebaran kuesioner pada 100 Wisatawan yang diperoleh melalui insidental sampling. Kemudian dilakukan pengujian dengan melakukan uji koefisien korelasi, uji koefisien determinasi dan persamaan regresi. Hasil penelitian Kualitas Pelayanan Terhadap Penjualan Kamar Hotel Bagi Wisatawan Pengguna Jasa Hotel di Bandung menunjukkan bahwa hasil uji koefisien korelasi sebesar 0,882 yang menunjukkan pelayanan memiliki hubungan yang sangat kuat terhadap penjualan kamar. Uji koefisien determinasi diperoleh sebesar 77,8\% yang berarti kualitas pelayanan berpengaruh terhadap penjualan kamar. Persamaan regresi bernilai $\mathrm{Y}=$ $10,57+0,858$. $\mathrm{X}$ hal ini menunjukkan adanya pengaruh positif dan kualitas pelayanan menunjukkan hubungan yang searah.
\end{abstract}

Kata Kunci: Kualitas Pelayanan, Penjualan, Wisatawan

\begin{abstract}
Companies engaged in the service sector view customers as an important factor. Customers who are satisfied with the services offered are a positive sign for a company. In order to realize customer satisfaction, the company must be able to provide services according to or exceed customer expectations, because the better the service provided, the more satisfied the customer will be. This will have an effect on increasing the profit earned by the company. This study aims to determine the quality of service to sales of hotel rooms for tourists who use hotel services in Bandung. The research method used in this study is a quantitative method, through distributing questionnaires to 100 tourists obtained through incidental sampling. Then tested by testing the correlation coefficient, test the coefficient of determination and regression equation. The results of the research on Service Quality on Hotel Room Sales for Tourists Hotel Service Users in Bandung show that the results of the correlation coefficient test are 0.882 which shows that service has a very strong relationship with room sales. The coefficient of determination test was obtained at $77.8 \%$, which means that service quality has an effect on room sales. The regression equation is $Y=10.57+0.858 . X$ this shows a positive influence and service quality shows a unidirectional relationship.
\end{abstract}

Keywords: Service Quality, Sales, Tourists

Diterima: 9 Juli 2020, Direvisi: 26 Agustus 2020, Diterbitkan: 27 Agustus 2020 


\section{PENDAHULUAN}

Dewasa ini banyak perusahaan termasuk perusahaan jasa menyatakan bahwa tujuan utama perusahaan adalah ingin memberikan kepuasan kepada pelanggan. Maka persaingan dalam dunia bisnis mendorong munculnya gagasan-gagasan baru dalam menciptakan produk atau jasa yang memberikan nilai lebih kepada konsumen. Bentuk penilaian konsumen terhadap pelayanan yang diterima dapat dijadikan tolak ukur kualitas pelayanan suatu perusahaan. Perilaku konsumen menjadi perhatian utama bagi perumus strategi promosi dalam suatu perusahaan terutama dalam hal peningkatan keuntungan.

Pembelian konsumen merupakan nafas bagi perusahaan dimana itu adalah sumber dari keuntungan perusahaan. Berhasil tidaknya suatu usaha perhotelan sangat tergantung pada room occupancy rate (tingkat hunian kamar), yakni persentase dari kamar-kamar hotel yang bisa terisi atau disewa oleh tamu dibandingkan dengan jumlah seluruh kamar yang dapat disewakan, diperhitungkan dalam jangka waktu tertentu (misalnya bulanan atau tahunan). Dari room occupancy rate ini bisa dilihat maju mundurnya hotel tersebut secara komersial, kemudian juga dapat dilihat dalam periode apa hotel berada dalam low season atau peak season. Menurut Triana, Yunus, and Chan (2015:2) "occupancy rate diatas $60 \%$ menjadi syarat minimum sebuah hotel dapat beroperasi secara sehat. Banyak hotel yang menargetkan occupancy rate diatas $80 \%$ untuk menjamin sustainability bisnis hotelnya termasuk pengembangannya dimasa yang akan datang”.

Tidak selamanya industri perhotelan menikmati occupancy rate yang tinggi. Meningkatnya tingkat persaingan karena dipicu oleh meningkatnya jumlah kamar dari sisi supply yang tidak diimbangi dengan jumlah demand membuat management hotel harus lebih kreatif menyusun dan menjalankan strategi pemasarannya. Disinilah pentingnya tugas dan peran bagian pemasaran pada suatu hotel yaitu mengusahakan agar kamar - kamar yang pada waktu - waktu sepi (low-season) dapat terisi disamping itu harus mempertahankan tingkat hunian pada saat peak season.

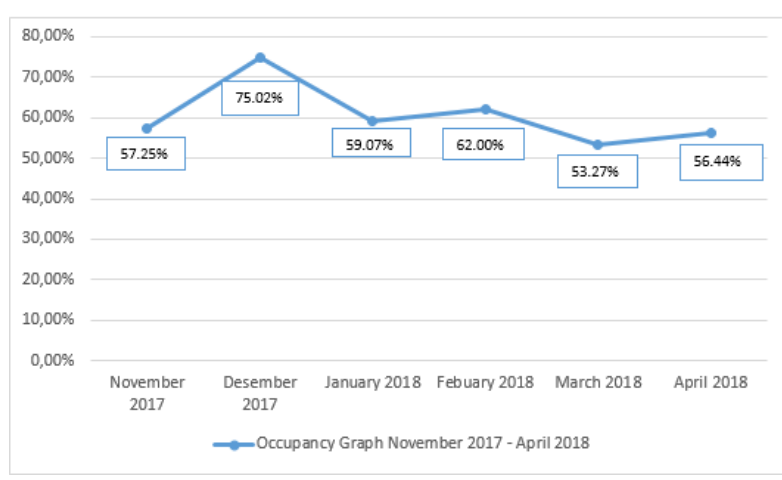

\section{Gambar 1. Occupancy Rate November 2017 - April 2018}

Grafik diatas adalah occupancy rate atau tingkat hunian kamar di Hotel Bandung pada bulan November 2017 sampai April 2018. Tingkat tertinggi hunian kamar pada grafik diatas ada bulan Desember 2017 dengan presentase $75.02 \%$ sedangkan tingkat terendah ada pada bulan Maret 2018 dengan presentase $53.27 \%$. Terdapat Gap yang tinggi antara occupancy rate bulan Desember 2017 dengan bulan lainnya yakni sekitar 20\% maka dapat diketahui bahwa tingkat penjualan kamar yang terjadi tidak stabil setiap bulannya. Keputusan pembelian, pemilihan pangsa pasar, penerapan sistem marketing dan promosi akan mempengaruhi tingkat penjualan kamar. Berdasarkan latar belakang yang telah diuraikan, maka tujuan penelitian ini mengkaji kualitas pelayanan dan penjualan kamar yang dilaksanakan oleh Hotel penyedia jasa.

\section{LITERATUR REVIEW}

\section{Kualitas Pelayanan}

Menurut ISO 9000 dalam Lupiyoadi (2013:212) Kualitas merupakan perpaduan antara sifat dan karakteristik yang menentukan sejauh mana keluaran dapat memenuhi persyaratan kebutuhan pelanggan. Pelanggan yang menentukan dan menilai sampai seberapa jauh sifat dan karakteristik tersebut memenuhi kebutuhannya. Terdapat 3 orientasi kualitas yang seharus nya konsisten satu sama lain, yaitu persepsi konsumen, produksi/jasa, dan proses.

Ivancevich, Lorenzi Skinner dan Crosby dalam Ratminto and Winarsih (2013:2), mengemukakan bahwa Pelayanan adalah produk-produk yang tidak kasat mata (tidak dapat diraba) yang melibatkan usaha-usaha manusia dengan menggunakan peralatan.

Kotler \& Keller dalam Tjiptono and Chandra (2016:13) mendefinisikan Pelayanan sebagai setiap tindakan atau perbuatan yang dapat 
ditawarkan oleh suatu pihak kepada pihak lain yang pada dasarnya bersifat intangible (tidak berwujud fisik) dan tidak menghasilkan kepemilikan sesuatu. Sedangkan definisi yang lebih rinci diberikan oleh Gronroos dalam Tjiptono and Chandra (2016:13) bahwa Pelayanan adalah proses yang terdiri atas serangkaian aktivitas intangible yang biasanya (namun tidak harus selalu) terjadi pada interaksi antara pelanggan dan karyawan jasa dan/atau sumber daya fisik atau barang dan/atau sistem penyedia jasa, yang disediakan sebagai solusi atas masalah pelanggan.

Dari beberapa definisi diatas dapat dilihat bahwa pelayanan bersifat tidak kasat mata (intangible) yang terjadi sebagai akibat adanya interaksi antara pelanggan dengan karyawan atau hal-hal lain yang disediakan oleh perusahaan pemberi pelayanan. Bertujuan untuk memecahkan permasalahan anatara pelanggan dan perusahaan. Yakni pemenuhan kebutuhan dan harapan pelanggan juga perolehan laba bagi perusahaan.

\section{Penjualan Kamar}

Tjiptono and Chandra (2017:461) mendefinisikan penjualan merupakan program yang terdiri atas berbagai kegiatan pemasaran yang berusaha memperlancar dan mempermudah penyampaian barang dan jasa dari produsen kepada konsumen, sehingga pengguanaannya sesuai dengan yang diperlukan (jenis, jumlah, harga, tempat, dan saat dibutuhkan).

Selanjutnya Huegy dalam Alma (2013:111) mengatakan bahwa menjual adalah suatu metode yang paling tua dan paling efektif dalam menciptakan dan mendorong permintaan, mencari pembeli, dan melakukan penjualan. Sedangkan menurut Alma (2013:20) mengemukakan Penjualan dimulai dengan anggukan, tegur sapa antara penjual dan pembeli, menanyakan dan melihat-lihat barang, tawarmenawar, dan akhirnya klimaks terjadi transaksi. Tugas penjual di sini ialah membantu calon pembeli, mengarahkan dia menuju titik klimaks, yang memuaskan sehingga kelak menjadi langganan yang setia.

Berdasarkan uraian di atas dapat dilihat bahwa penjualan adalah serangkaian kegiatan dalam penyampaian barang dan jasa dari produsen ke konsumen. Kontak personal atau langsung dengan pembeli akhir atau konsumen dapat mempermudah dan memperlancar penyampaian produk dan jasa. Sehingga menciptakan dan mendorong permintaan, mencari pembeli yang berakhir dengan transaksi penjualan.

\section{METODOLOGI PENELITIAN}

Dalam penelitian ini metode yang digunakan adalah metode deskriptif kuantitatif yang mana hasil data tersebut diperoleh dari angket yang disebarkan oleh penulis kepada responden dengan teknik observasi dan penyebaran kuesioner. Populasi dalam penelitian ini adalah para wisatawan pengguna Hotel di Bandung yaitu dengan rata-rata 4000 customer per bulan yang dikalikan 6 (data 6 bulan) menjadi 24.000 customer. Pengambilan sampel yang digunakan dalam penelitian ini adalah teknik insidental sampling. Sampel yang merupakan Wisatawan Pengguna Layanan Hotel di Bandung dipilih secara acak berdasarkan kesediaan responden untuk mengisi kuesioner. Untuk menentukan jumlah sampel yang akan diteliti maka penulis menggunakan rumus menurut Slovin, yaitu:

$$
\begin{aligned}
& \mathrm{n}=\frac{\mathrm{N}}{\left(\mathrm{N} \cdot \mathrm{d}^{2}\right)+1} \\
& \mathrm{n}=\frac{24000}{24000 \cdot(0,1)^{2}+1} \\
& =\frac{24000}{24000(0,01)+1} \\
& =\frac{24000}{241}=99,58
\end{aligned}
$$

Berdasarkan hasil perhitungan di atas, maka di peroleh sampel sebanyak 99.58 yang kemudian dibulatkan menjadi 100 responden Menurut Ardianto (2014:188) Validitas suatu alat ukur ditentukan oleh sejauhmana isi alat ukur tersebut mewakili semua aspek yang dianggap sebagai aspek kerangka konsep. Validitas membantu seseorang dalam mempertanggung jawabkan suatu penelitian. Menurut Ardianto 2014:189) Realiabilitas adalah indeks yang menunjukan sejauhmana suatu alat ukur dapat dipercaya atau dapat diandalkan. Reliabilitas menunjukan sejauhman hasil pengukuran dalam konsistensinya.

\section{HASIL DAN PEMBAHASAN \\ Analisis Kualitas Pelayanan}

Dalam penelitian ini, penulis ingin mengetahui tanggapan responden menganai kualitas pelayanan. Pada variable pelayanan, penilaian dilakukan dengan 5 indikator, diantaranya adalah keandalan (reliability), daya tanggap (responsiveness), dan jaminan (assurance), 
empati (empathy), bukti fisik (tangible) Berikut adalah deskripsi mengenai variable kualitas pelayanan.

Berdasarkan Tabel 1, jumlah skor penilaian kualitas pelayanan adalah sebesar 8042. Hasil tersebut diperoleh dari rekapitulasi setiap jawaban yang dikalikan dengan bobot nilai skala likert. Sehingga dapat diketahui bahwa persentasi kualitas pelayanan sebesar $80,42 \%$ yang artinya kualitas pelayanan Hotel di Bandung dikategorikan baik karena hasil presentase mendekati angka 100\%. Hasil tersebut diperoleh dari jumlah skor penilaian dibagi dengan jumlah responden (100), nilai bobot tertinggi pada skala likert yaitu (5), jumlah item pertanyaan pada variabel kualitas pelayanan (20) dikalikan dengan $100 \%$.

Tabel 1. Persentase Penilaian Variabel Pelayanan

\begin{tabular}{|c|c|c|c|c|c|c|c|}
\hline \multirow[b]{2}{*}{ No } & \multicolumn{5}{|c|}{ Skor Penilaian } & \multirow{2}{*}{$\begin{array}{c}\text { Jumla } \\
\text { h }\end{array}$} & \multirow[b]{2}{*}{$\%$} \\
\hline & $\begin{array}{l}\text { SS } \\
(5)\end{array}$ & $\begin{array}{c}S \\
(4)\end{array}$ & $\begin{array}{l}\text { KS } \\
\text { (3) }\end{array}$ & $\begin{array}{l}\text { TS } \\
\text { (2) }\end{array}$ & $\begin{array}{c}\text { STS } \\
(1)\end{array}$ & & \\
\hline 1 & 185 & 180 & 33 & 6 & 4 & 408 & $82 \%$ \\
\hline 2 & 150 & 204 & 33 & 10 & 3 & 400 & $80 \%$ \\
\hline 3 & 145 & 208 & 33 & 8 & 4 & 398 & $80 \%$ \\
\hline 4 & 145 & 216 & 30 & 10 & 2 & 403 & $81 \%$ \\
\hline 5 & 155 & 196 & 39 & 6 & 4 & 400 & $80 \%$ \\
\hline 6 & 165 & 188 & 33 & 12 & 3 & 401 & $80 \%$ \\
\hline 7 & 155 & 196 & 36 & 6 & 5 & 398 & $80 \%$ \\
\hline 8 & 155 & 216 & 21 & 8 & 4 & 404 & $81 \%$ \\
\hline 9 & 150 & 216 & 27 & 6 & 4 & 403 & $81 \%$ \\
\hline 10 & 175 & 192 & 30 & 6 & 4 & 407 & $81 \%$ \\
\hline 11 & 175 & 184 & 33 & 6 & 5 & 403 & $81 \%$ \\
\hline 12 & 145 & 200 & 42 & 6 & 4 & 397 & $79 \%$ \\
\hline 13 & 160 & 184 & 42 & 10 & 3 & 399 & $80 \%$ \\
\hline 14 & 155 & 192 & 36 & 8 & 5 & 396 & $79 \%$ \\
\hline 15 & 150 & 192 & 36 & 10 & 5 & 393 & $79 \%$ \\
\hline 16 & 135 & 192 & 51 & 6 & 5 & 389 & $78 \%$ \\
\hline 17 & 205 & 172 & 27 & 10 & 2 & 416 & $83 \%$ \\
\hline 18 & 205 & 176 & 24 & 8 & 3 & 416 & $83 \%$ \\
\hline 19 & 175 & 176 & 39 & 10 & 3 & 403 & $81 \%$ \\
\hline 20 & 185 & 184 & 24 & 12 & 3 & 408 & $82 \%$ \\
\hline & & & & & & 8042 & \\
\hline & $\frac{8}{100}$ & $\frac{42}{5 \times 2}$ & & & 4 & & \\
\hline
\end{tabular}

\section{Analisis Penjualan Kamar}

Dalam penelitian ini, penulis ingin mengetahui tanggapan responden mengenai penjualan kamar Hotel di Bandung. Penilaian dilakukan dengan 7 indikator, diantaranya adalah tanggapan mengenai Produk (product), Harga (price), Lokasi/tempat (place), Promosi (promotion), Proses (process), Layanan Pelanggan (costumer service). Adapun deskripsi tanggapan responden mengenai penjualan dapat dilihat sebagai berikut.

\section{Tabel 2. Persentase Penilaian Variabel} Penjualan

\begin{tabular}{|c|c|c|c|c|c|c|c|}
\hline \multirow[b]{2}{*}{ No } & \multicolumn{5}{|c|}{ Skor Penilaian } & \multirow[b]{2}{*}{ Jumlah } & \multirow[b]{2}{*}{$\%$} \\
\hline & $\begin{array}{l}\text { SS } \\
(5)\end{array}$ & $\begin{array}{c}S \\
(4)\end{array}$ & $\begin{array}{l}\text { KS } \\
\text { (3) }\end{array}$ & $\begin{array}{l}\mathrm{TS} \\
\text { (2) }\end{array}$ & $\begin{array}{c}\text { STS } \\
\text { (1) }\end{array}$ & & \\
\hline 1 & 170 & 180 & 45 & 6 & 3 & 404 & $81 \%$ \\
\hline 2 & 120 & 204 & 51 & 10 & 3 & 388 & $78 \%$ \\
\hline 3 & 110 & 228 & 42 & 8 & 3 & 391 & $78 \%$ \\
\hline 4 & 130 & 224 & 27 & 12 & 3 & 396 & $79 \%$ \\
\hline 5 & 140 & 192 & 54 & 4 & 4 & 394 & $79 \%$ \\
\hline 6 & 140 & 204 & 39 & 12 & 2 & 397 & $79 \%$ \\
\hline 7 & 140 & 204 & 36 & 10 & 4 & 394 & $79 \%$ \\
\hline 8 & 135 & 196 & 51 & 8 & 3 & 393 & $79 \%$ \\
\hline 9 & 200 & 168 & 33 & 8 & 3 & 412 & $82 \%$ \\
\hline 10 & 200 & 164 & 33 & 10 & 3 & 410 & $82 \%$ \\
\hline 11 & 170 & 192 & 36 & 6 & 3 & 407 & $81 \%$ \\
\hline 12 & 170 & 172 & 45 & 10 & 3 & 400 & $80 \%$ \\
\hline 13 & 170 & 184 & 36 & 10 & 3 & 403 & $81 \%$ \\
\hline 14 & 145 & 204 & 36 & 8 & 4 & 397 & $79 \%$ \\
\hline 15 & 145 & 200 & 42 & 8 & 3 & 398 & $80 \%$ \\
\hline 16 & 135 & 196 & 51 & 8 & 3 & 393 & $79 \%$ \\
\hline 17 & 140 & 204 & 39 & 12 & 2 & 397 & $79 \%$ \\
\hline 18 & 140 & 204 & 36 & 10 & 4 & 394 & $79 \%$ \\
\hline 19 & 135 & 196 & 51 & 8 & 3 & 393 & $79 \%$ \\
\hline 20 & 110 & 228 & 42 & 8 & 3 & 391 & $78 \%$ \\
\hline & & & & & & 7952 & \\
\hline & $\frac{52}{5 x}$ & & 0 & & 520 & & \\
\hline
\end{tabular}

Berdasarkan tabel diatas, jumlah skor penilaian penjualan adalah sebesar 7952. Hasil tersebut diperoleh dari rekapitulasi setiap jawaban yang dikalikan dengan bobot nilai skala likert. Sehingga dapat diketahui bahwa persentasi penjualan sebesar $79,52 \%$ yang artinya penjualan 
Kamar Hotel di Bandung dikategorikan baik karena hasil presentase mendekati angka $100 \%$. Hasil tersebut diperoleh dari jumlah skor penilaian dibagi dengan jumlah responden (100), nilai bobot tertinggi pada skala likert yaitu (5), jumlah item pertanyaan pada variable penjualan (20) dikalikan dengan $100 \%$.

\section{Uji Validitas}

Tabel 3. Hasil Uji Validitas Instrumen

\begin{tabular}{|c|c|c|c|c|}
\hline Var & $\begin{array}{c}\text { Butir } \\
\text { Pertanyaan }\end{array}$ & $\begin{array}{l}\text { Corrected } \\
\text { Item Total } \\
\text { Correlation } \\
\text { (r hitung) }\end{array}$ & $r$ tabel & Ket \\
\hline \multirow{20}{*}{$(\mathrm{X})$} & 1 & 0,699 & 0,195 & Valid \\
\hline & 2 & 0,838 & 0,195 & Valid \\
\hline & 3 & 0,892 & 0,195 & valid \\
\hline & 4 & 0,890 & 0,195 & valid \\
\hline & 5 & 0,814 & 0,195 & valid \\
\hline & 6 & 0,877 & 0,195 & valid \\
\hline & 7 & 0,892 & 0,195 & valid \\
\hline & 8 & 0,858 & 0,195 & valid \\
\hline & 9 & 0,930 & 0,195 & valid \\
\hline & 10 & 0,912 & 0,195 & valid \\
\hline & 11 & 0,874 & 0,195 & valid \\
\hline & 12 & 0,899 & 0,195 & valid \\
\hline & 13 & 0,876 & 0,195 & valid \\
\hline & 14 & 0,891 & 0,195 & valid \\
\hline & 15 & 0,854 & 0,195 & valid \\
\hline & 16 & 0,861 & 0,195 & valid \\
\hline & 17 & 0,841 & 0,195 & valid \\
\hline & 18 & 0,864 & 0,195 & valid \\
\hline & 19 & 0,827 & 0,195 & valid \\
\hline & 20 & 0,842 & 0,195 & valid \\
\hline \multirow{20}{*}{$(\mathrm{Y})$} & 1 & 0,853 & 0,195 & valid \\
\hline & 2 & 0,884 & 0,195 & valid \\
\hline & 3 & 0,902 & 0,195 & valid \\
\hline & 4 & 0,856 & 0,195 & valid \\
\hline & 5 & 0,851 & 0,195 & valid \\
\hline & 6 & 0,901 & 0,195 & valid \\
\hline & 7 & 0,863 & 0,195 & valid \\
\hline & 8 & 0,896 & 0,195 & valid \\
\hline & 9 & 0,788 & 0,195 & valid \\
\hline & 10 & 0,859 & 0,195 & valid \\
\hline & 11 & 0,822 & 0,195 & valid \\
\hline & 12 & 0,833 & 0,195 & valid \\
\hline & 13 & 0,842 & 0,195 & valid \\
\hline & 14 & 0,848 & 0,195 & valid \\
\hline & 15 & 0,837 & 0,195 & valid \\
\hline & 16 & 0,896 & 0,195 & valid \\
\hline & 17 & 0,901 & 0,195 & valid \\
\hline & 18 & 0,863 & 0,195 & valid \\
\hline & 19 & 0,896 & 0,195 & valid \\
\hline & 20 & 0,902 & 0,195 & valid \\
\hline
\end{tabular}

Uji validitas digunakan untuk mengukur ketepatan suatu item dalam kuesioner, untuk mengetahui apakah kuesioner tersebut sudah tepat dalam mengukur apa yang ingin diukur.

Berdasarkan penelitian ini, diketahui $\mathrm{n}$ adalah 100 sampel dan $\mathrm{k}$ adalah 2 (kualitas pelayanan dan penjualan kamar) sehingga besarnya df adalah $100-2=98$ dengan alpha $0,05(\alpha=5 \%)$ didapat nilai $\mathrm{r}$ tabel 0,195 . Apabila $\mathrm{r}$ hitung dan nilai $\mathrm{r}$ positif, maka butir pertanyaan tersebut dikatakan valid, dan sebaliknya apabila $r$ hitung lebih kecil dari $r$ tabel maka, butir pertanyaan itu tidak valid. Hasil analisis validitas dapat dilihat pada Tabel .3

\section{Uji Reliabilitas}

Mengukur reliabilitas dengan menggunakan uji statistik adalah dengan mencari cronbach alfa $(\alpha)$. Sesuatu dikatakan reliable apabila memiliki cronbach alfa lebih dari 0,06 (>0,06). Hasil analisis reliabilitas dapat dilihat pada tabel berikut.

Tabel 4. Hasil Uji Reliabilitas

\begin{tabular}{|c|c|c|c|}
\hline $\begin{array}{c}\text { Variabe } \\
\text { I }\end{array}$ & Item & $\begin{array}{c}\text { Alph } \\
\text { a }\end{array}$ & $\begin{array}{c}\text { Keteran } \\
\text { gan }\end{array}$ \\
\hline $\mathrm{X}$ & 20 & 0,984 & Reliable \\
\hline $\mathrm{Y}$ & 20 & 0,984 & Reliable \\
\hline
\end{tabular}

Berdasarkan tabel diatas, dapat diketahui bahwa masing-masing variabel dalam penelitian ini memiliki cronbach alfa lebih dari 0,60 $(\alpha>$ $0,60)$. Sehingga dapat disimpulkan bahwa variabel $\mathrm{X}$ dan $\mathrm{Y}$ adalah reliabel.

\section{Uji Koefisien Korelasi}

Untuk mengetahui nilai dari koefisien korelasi (r) yang berfungsi untuk mengetahui kekuatan hubungan antara variabel pelayanan dan variabel kepuasan pelanggan, maka perhitungan berdasarkan data hasil kuesioner adalah sebagai berikut:

$$
\begin{aligned}
& \mathrm{r}=\frac{\mathrm{n} \sum \mathrm{XY}-\left(\sum \mathrm{X}\right)\left(\sum \mathrm{Y}\right)}{\sqrt{\left\{\mathrm{n} \sum \mathrm{X}^{2}-\left(\sum \mathrm{X}\right)^{2}\right\}\left\{\mathrm{n} \sum \mathrm{Y}^{2}-\left(\sum \mathrm{X}\right)^{2}\right\}}} \\
& =\frac{100.663604-(8035)(7952)}{\sqrt{\left\{100.674337-(8035)^{2}\right\}\left[100.659532-(7952)^{2}\right\}}} \\
& =\frac{66360400-63894320}{\sqrt{\{67433700-64561225\}\{65953200-6323404)}}
\end{aligned}
$$




$$
\begin{aligned}
& =\frac{2466080}{(2872475)(2718896)} \\
& =\frac{2466080}{2794631} \\
& =0,882
\end{aligned}
$$

Nilai $\mathrm{r}$ yang didapat dari hasil perhitungan koefisien korelasi adalah sebesar 0,882. Berdasarkan tingkat korelasi dan kekuatan hubungan menurut Sugiyono (2013:214), angka 0,882 berada pada range $0,80-1,000$ yang memiliki tingkat hubungan yang sangat kuat. Hal ini menujukkan bahwa pelayanan memiliki hubungan yang sangat kuat dengan penjualan kamar di Hotel Crowne Plaza Bandung.

\section{Uji Koefisien Determinasi}

Dalam menentukan nilai dari koefisien determinasi (r2) berfungsi untuk mengetahui seberapa besar pengaruh variabel pelayanan pada variabel penjualan. Maka perhitungan berdasarkan data hasil kuesioner adalah sebagai berikut:

$$
\begin{aligned}
\mathrm{KD} & =\mathrm{r}^{2} \mathrm{x} 100 \% \\
& =(0,882)^{2} \times 100 \% \\
& =0,778 \times 100 \% \\
& =77,8 \%
\end{aligned}
$$

Berdasarkan hasil perhitungan koefisien determinasi, maka diperoleh nilai r2 sebesar $77,8 \%$. Nilai koefisien determinasi bernilai positif, hal ini menunjukkan bahwa pelayanan mempengaruhi penjualan kamar di Hotel, sedangkan sisanya $22,2 \%$ penjualan kamar dipengaruhi oleh variabel lain yang tidak diteliti dalam penelitian ini.

\section{Uji Persamaan Regresi}

Untuk melakukan prediksi seberapa tinggi nilai variabel pelayanan yang dipengaruhi oleh variabel penjualan. Maka dapat dihitung dengan menggunakan rumus sebagai berikut $\mathrm{Y}=\mathrm{a}+\mathrm{b} . \mathrm{X}$ Dikarenakan nilai konstanta a dan $b$ belum diketahui, maka nilai konstanta a dan b perlu dicari terlebih dahulu. Untuk mengetahui nilai konstanta b, maka digunakan rumus sebagai berikut:

$$
\begin{aligned}
& \mathrm{b}=\frac{\mathrm{n} \cdot \sum \mathrm{XY}-\sum \mathrm{X} \cdot \sum \mathrm{Y}}{\mathrm{n} \cdot \sum \mathrm{X}^{2}-\left(\sum \mathrm{X}\right)^{2}} \\
& =\frac{100 \cdot 663604-8035 \cdot 7952}{100 \cdot 674337-(8035)^{2}} \\
& =\frac{66360400-63894320}{67433700-64561225} \\
& =\frac{2466080}{2872475} \\
& =0,858
\end{aligned}
$$

Berdasarkan perhitungan tersebut, maka dapat dilihat bahwa nilai konstanta $\mathrm{b}$ adalah sebesar 0,858 . Selanjutnya untuk mengetahui nilai konstanta a, maka digunakan rumus sebagai berikut:

$\mathrm{a}=\frac{\sum \mathrm{Y}-\mathrm{b} \cdot \sum \mathrm{X}}{\mathrm{n}}$

$$
\begin{aligned}
& =\frac{7952-0,858 \cdot 8035}{100} \\
& =\frac{7952-6894,03}{100} \\
& =\frac{1057,97}{100}
\end{aligned}
$$

$=10,57$

Dari perhitungan tersebut, maka dapat diketahui bahwa nilai konstanta a adalah sebesar 10,57. Maka berdasarkan hasil perhitungan nilai konstanta a dan $b$ tersebut, diperoleh nilai konstanta a sebesar 10,57 dan nilai konstanta $b$ sebesar 0,858 . Nilai konstanta a dan b tersebut digunakan untuk mengetahui persamaan regresi. Oleh karena itu didapat persamaan regresi sebagai berikut:

$\mathrm{Y}=10,57+0,858 . \mathrm{X}$

Konstanta a sebesar 10,57 bernilai positif berarti dengan adanya pengaruh pelayanan, maka nilai penjualan akan ada perubahan atau meningkat. Nilai konstanta b memiliki arah positif dalam pengaruhnya terhadap penjualan dengan nilai sebesar 0,858 . Dengan adanya pengaruh positif ini, menunjukkan bahwa pelayanan menunjukkan 
hubungan yang searah. Apabila variabel pelayanan mengalami peningkatan, maka akan menyebabkan penjualan semakin tinggi.

\section{KESIMPULAN DAN REKOMENDASI}

Dari hasil penelitian tentang Kualitas Pelayanan Terhadap Penjualan Kamar Bagi wisatawan Pengguna Jasa Layanan Hotel di Bandung, maka dapat ditarik kesimpulan. Hasil penelitian terhadap Kualitas pelayanan menunjukkan bahwa dari keseluruhan pernyataan mengenai kualitas pelayanan yang terdiri dari reliabilitas (reliability), daya tanggap (responsiveness), jaminan (assurance), empati (empathy), dan bukti fisik (tangibles) didapatkan tanggapan responden positif dengan menyatakan kualitas pelayanan Jasa Layanan Hotel adalah baik. Berdasarkan hasil penelitian terhadap penjualan Kamar Hotel menunjukan bahwa dari pernyataan mengenai penjualan yang terdiri dari produk (product), harga (price), lokasi/tempat (place), promosi (promotion), proses (process), dan layanan pelanggan (customer services) didapatkan tanggapan responden menunjukkan persepsi positif.

Bagi para pengusaha Perhotelan diharapkan kualitas pelayanan yang dilakukan sekarang ini dapat dipertahankan berdasarkan perhitungan koefisien korelasi $\mathrm{r}=0,882$ yang berarti pengaruh kualitas pelayanan terhadap penjualan kamar adalah sangat kuat. Dengan konsisten memberikan pelayanan terhadap pelanggan dari waktu ke waktu. Bagi perusahaan diharapkan juga harus mampu meningkatkan kualitas pelayanan yang sudah baik ini, dengan terus meningkatkan kualitas pelayanan, menganalisis harapan pelanggan, dan menyesuaikan pemberian pelayanan sesuai dengan harapan pelanggan. Dengan terpenuhinya harapan pelanggan, dapat meningkat pula laba bagi perusahaan. Bagi peneliti selanjutnya, hasil penelitian ini dapat dijadikan sebagai rujukan dan perlu dikembangkan lebih lanjut dalam melakukan penelitian selanjutnya terlebih untuk mengetahui variabel-variabel lain yang menunjukkan kualitas pelayanan dapat meningkatkan penjualan kamar.

\section{REFERENSI}

Alma, Buchari. 2013. Manajemen Pemasaran Dan Pemasaran Jasa. Bandung: Alfabeta. www.cvalfabeta.com.

Ardianto, Elvinaro. 2014. Metodologi Penelitian Untuk Public Relations Kuantitatif Dan Kualitatif. Bandung: Simbiosa Rekatama Media. www.simbiosarekatama.com.
Lupiyoadi, Rambat. 2013. Manajemen Pemasaran. Edited by Dedy A. Halim. Edisi 3. Jakarta: Salemba Empat. http://www.penerbitsalemba.com.

Ratminto, and Atik Septi Winarsih. 2013. Manajemen Pelayanan. Yogyakarta: Pustaka Pelajar.

Tjiptono, Fandy, and Gregorius Chandra. 2016. Service, Quality \& Satisfaction. Edisi 4. Yogyakarta: Andi offset.

Tjiptono, Fandy, and Gregorius Chandra. 2017. Pemasaran Strategik. Edisi 3. Yogyakarta: Andi offset.

Triana, Rini, Mukhlis Yunus, and Syafruddin Chan. 2015. "Pengaruh Program Bauran Promosi Terhadap Peningkatan Citra Perusahaan Dalam Meningkatkan Keputusan Untuk Menginap Di Hotel Berbintang Tiga Di Banda Aceh.” Jurnal Manajemen Pascasarjana Universitas Syiah Kuala Volume 4,. 